The report's call for more attention to be paid to ICF reflects a wider concern that Europe's fusion strategy may be off course. It asserts that "the weight and scope of the EU Fusion Programme" makes necessary a "thorough review of the scientific, technical and socio-economic prospects of its future R\&D goals".

Indeed, parts of the report represent a thinly veiled attack on ITER. One member of the working group points out that, although the language of the report is polite "for the insider there are some very critical question marks about ITER".

This reflects growing concern among some fusion researchers that ITER may not achieve its stated goals. To meet these, ITER's performance would need to fulfil highly optimistic predictions, even though its operation would rely on several untested technologies. Any shortfall would result in a conspicuous and expensive failure that could set back support for fusion by decades.

Hans Karow, the secretary of the working party, is himself sceptical that ITER would achieve ignition. "It does not make sense to enter the pseudo-technical colossus of ITER before the physics case has been solved," he says. The report claims that inertial confinement "might still emerge as a superior way towards fusion energy".

Indeed, inertial confinement could in theory fuse deuterium with deuterium. This provides it with a big potential advantage over magnetic confinement, which can only fuse deuterium with tritium, as it would both eliminate the need to use radioactive tritium, and avoid the production of highenergy neutrons that make the first wall of the tokamak radioactive and weaken its structure. The first wall of a tokamak at $10^{7}$ rads per hour is the hottest radioactive working environment on Earth.

Similarly, Sir William Mitchell, a former head of Britain's Science and Engineering Research Council, and a member of the working party, claims that although MCF may "look like big engineering", it is still in the research phase. "If both magnetic and inertial confinement are at the research stage, we should complete this stage before any decision [on how to proceed] is made."

The European Commission is already due to carry out a routine review of fusion research later this year. But the commission has now also agreed to a broader review that would include comparisons of fusion energy with other sources of energy and assess technical and environmentai problems. Members of the panel will be nominated within the next few weeks.

JET director Martin Keilhacker, agrees that pressure is growing for a review of ITER as now envisaged. But he argues that some of this pressure is merely the result of budgetary politics, particularly in the United States, and maintains that "the ITER objectives are the right ones, and now is the right time to build it".

Declan Butler

\title{
Biotech industry woos MEPs to ease regulatory burden
}

Munich. Europe's biotechnology industry. still smarting from last year's rejection by the European Parliament of an attempt to harmonize patent legislation, is making an unprecedented effort to engage politicians in a dialogue aimed at reducing regulatory burdens on the industry.

Despite a report from the consultancy group Ernst and Young last week, indicating a 20 per cent increase in the number of biotechnology companies in Europe last year, the industry argues that the gap between Europe and the United States and Japan is increasing.

The first of a proposed series of information-exchange meetings took place in Strasbourg last week between representatives of the biotechnology industry and members of the European Parliament - who, following the Maastricht Treaty, can effectively veto any legislation regulating or promoting the industry's activities.

The initiative for the meeting came from Christof Tannert, a German socialist member of the European Parliament (MEP). Tannert is keen to see the industry adhere to strict safety standards, and is seeking a permanent structure for such meetings similar to the European Energy Foundation set up in 1981 to promote dialogue between MEPs and the energy industry.

Much of the industry's concern is focused on the revised draft directive on patenting of biotechnological products, which was drawn

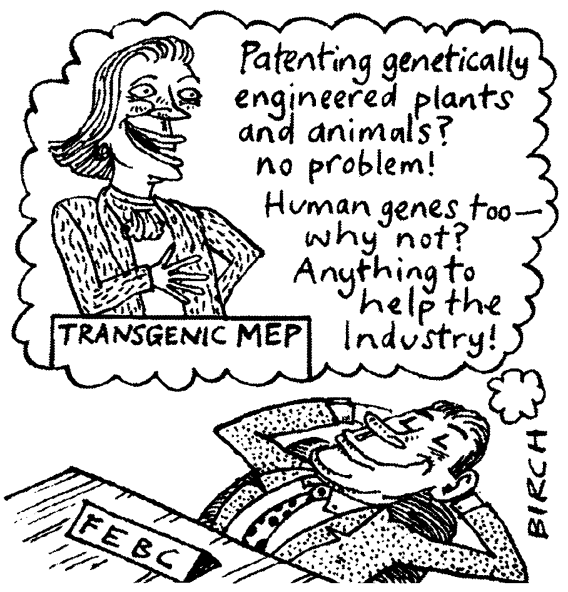

up and approved by the European Commission last December after an earlier version had been rejected by the European Parliament (see Nature 374, 103; 1995).

The new directive, which has been approved by the Forum for European Bioindustry Coordination (FEBC), a Brusselsbased umbrella group for industries with biotechnology interests, clarifies some of the issues that had concerned MEPs. But it still allows the patenting of human genes, as well as transgenic animals and plants, which many MEPs oppose on ethical grounds.

The forum wants this latter issue to be "explicitly resolved" during discussion of the directive, because of the uncertainty over the scope of patent legislation. Indeed, the European Patent Office (EPO), which is independent of the commission, has temporarily stopped granting patents on living organisms following a ruling by its Board of Appeals in February last year that a transgenic plant represents a collection of new varieties so - because the European Patent Convention disallows patents on plant and animal varieties - is unpatentable.

Confusion about the interpretation of the convention, which includes continuing uncertainty about the fate of the patent application on the Harvard 'oncomouse'. has helped to focus attention on the European Parliament. The parliament will hold a public hearing on the new directive in Brussels on 10 and 11 June, and is expected to give the commission's proposals a first reading in November.

As the revised draft directive was drawn up after extensive discussions with the parliament, commission officials are optimistic that it will be approved. But parliament's mood can change rapidly in response to unexpected events. And one such event, according to Peter Stevenson of Compassion in World Farming, a British pressure group opposing the oncomouse patent, is current concern about bovine spongiform encephalopathy and its association with feeding cattle, which are naturally herbivores, with sheep brain.

The unpredicted consequences of such "interference with nature", suggests Stevenson, "means that people are now much more ready to accept our arguments that genetic engineering of animals, and therefore their patenting, is wrong".

Industry is keenly aware of the parliament's sensitivity to public opinion. According to Peter Doyle, an executive director of the British life sciences company Zeneca, it is essential for industrial biotechnologists to remain in a "continuing dialogue" with Europe's elected representatives.

Doyle says that the European biotechnology industry needs a much more supportive regulatory environment. He agrees with some of the more positive signs described in the Ernst and Young report, but adds that "a small base growing at a rate of 20 per cent cannot catch up with a large base [as in the United States] growing at a slower rate".

He also points out that 26 of Europe's 28 publicly quoted companies are in the United Kingdom, where regulations are more flexible than other European countries.

Alison Abbott 